\title{
INDEXES OF NITRIC OXIDE SYSTEM IN EXPERIMENTAL ANTIPHOSPHOLIPID SYNDROME
}

\author{
O. Z. YAREMCHUK ${ }^{凶}$, K. A. POSOKHOVA, I. P. KUZMAK, \\ M. I. KULITSKA, I. M. KLISHCH, M. M. KORDA \\ I. Horbachevsky Ternopil National Medical University, Ukraine; \\ ৫-mail: yaremchuk@tdmu.edu.ua
}

Received: 11 November 2019; Accepted: 21 January 2020

Antiphospholipid syndrome (APS) is an autoimmune disease characterized by the presence of antibodies to negatively charged membrane phospholipids (aPL). Endothelial dysfunction is one of the most dangerous APS manifestations followed by thrombosis, placental insufficiency and often foetal death due to circulatory disorders in placenta blood vessels. It is established that synthesis and bioavailability of nitric oxide (NO) in the endothelium are impaired at APS, but the role of NO system in pregnancy failure at this pathology remains ambiguous. The aim of this research was to estimate the indexes of the nitric oxide system in animals with an experimental antiphospholipid syndrome before pregnancy and on the $18^{\text {th }}$ day of pregnancy, without treatment and under treatment with nitric oxide synthesis modulators (L-arginine and aminoguanidine). In the blood serum and liver of the BALB/c mice with experimental APS, the content of eNOS and iNOS by ELISA and the level of $\mathrm{NO}_{2}^{-}$and $\mathrm{NO}_{3}{ }^{-}$with the use of Gris reagent were determined before pregnancy and on the $18^{\text {th }}$ day of pregnancy. The data obtained indicate the relative inefficient NO production by eNOS and NO hyperproduction by iNOS in the blood serum and liver of mice in the pathogenesis of experimental APS. Thus, in mice with APS before pregnancy and on the $18^{\text {th }}$ day of the pregnancy, the eNOS content and $\mathrm{NO}_{2}^{-}$ level were decreased while the iNOS content and $\mathrm{NO}_{3}^{-}$level were increased compared to the indexes in the control animal group. L-arginine administration to the animals with APS at the follow-up periods resulted in an increased eNOS content and $\mathrm{NO}_{2}^{-}, \mathrm{NO}_{3}^{-}$levels in blood serum and liver with the simultaneous decrease in iNOS content in the liver as compared to indexes in untreated mice with APS. The combined use of L-arginine and selective iNOS inhibitor aminoguanidine caused a significant increase in eNOS content and a decrease in iNOS content followed by normalization of $\mathrm{NO}_{2}^{-}$and $\mathrm{NO}_{3}^{-}$levels in blood and liver of mice with experimental APS before pregnancy and on the $18^{\text {th }}$ day of pregnancy compared to untreated mice with APS.

Ke y w ord s: antiphospholipid syndrome, nitric oxide, eNOS, iNOS, L-arginine, aminoguanidine.

A ntiphospholipid syndrome (APS) is an autoimmune disease characterized by the presence of antibodies to negatively charged membrane phospholipids (aPL) in the blood [1-4]. Antibodies and cell membrane phospholipids interaction causes conformational and metabolic changes in membranes, cell dysfunction and blood clotting disorders. APS is manifested by vessels thrombosis of different sizes and localizations, stroke, obstetric pathology or thrombocytopenia [4-6]. In the case of gestational APS, the antibodies are formed predominantly to cardiolipin that leads to placental arterial thrombosis, which is liable to cause intrauterine foetal death or premature birth [7, 8]. Hypercoagulation in the plasmic haemostasis component, which develops under the influence of aPL, is followed by thrombosis in the microvasculature, placental insufficiency, chronic hypoxia and often foetal death due to acute circulatory disorders in placenta blood vessels [9, 10].

APS occurs in $27-42 \%$ cases among patients with refractory pregnancy loss. The foetal demise takes place in $90-95 \%$ of women with aPL without adequate treatment [10, 11].

(C) 2020 Yaremchuk O. Z. et al. This is an open-access article distributed under the terms of the Creative Commons Attribution License, which permits unrestricted use, distribution, and reproduction in any medium, provided the original author and source are credited. 
Practitioners still have difficulties in diagnosing and prescribing treatment for patients with APS [4]. Laboratory diagnostics for this disorder implies lupus anticoagulant testing and cardiolipin antibodies test, less often the determination of the level of specific antibodies to phosphatidylserine, phosphatidylinositol, phosphatidylethanolamine, as well as beta-2-glycoprotein-I, annexin V, prothrombin $[2,4]$. Antiphospholipid antibodies are recognized not only by phospholipids but also by the blood plasma proteins bound to the anionic surface. Plasma proteins are cofactors in aPL and endothelial cell's phospholipids interaction. The dysfunction of blood vessels endothelium is known to be followed by vasoconstriction and thrombus development [12-14]. Endothelial dysfunction combined with recurrent thrombosis is one of the main and most dangerous manifestations of APS $[15,16]$. It is also established that synthesis and bioavailability of nitric oxide (NO) in the endothelium at APS are impaired [6, 12, 17].

The enzyme responsible for NO biosynthesis is the nitric oxide synthase (NOS) which catalyzes the reaction of L-arginine, NADPH and oxygen conversion to the free radical NO, L-citrulline and NADP and exists in three isoforms: endothelial (eNOS, 1.14.13.39), inducible (iNOS, 1.14.13.39), and neuronal (nNOS, 1.14.13.39) [18].

Elucidation of NO system implication into APS development as well as the search for effective treatment of this pathology is an urgent and social issue $[3,10,19]$.

It is known that $\mathrm{NO}$ is involved in the regulation of the vascular tone and blood coagulation. NO synthesized by eNOS regulates numerous physiological processes, including thrombus formation, leukocyte adhesion, vascular permeability and blood cell migration [20]. The vascular effects of NO are: direct vasodilation, which depends on blood flow and is mediated by specific receptors; indirect vasodilation by inhibition of angiotensin vasoconstrictive effects and sympathetic innervation; antithrombotic activity by suppression of platelet adhesion to endothelium [21]. In addition, NO has an anti-inflammatory effect due to inhibition of leukocytes adhesion to the vascular endothelium and interception of superoxide anion and antiproliferative effect on unstriated muscle cells [22]. Vasoconstriction, thrombosis, inflammatory processes, hypertrophy and vascular stenosis occur when NO production or bioavailability is inhibited. Therefore the activity of endothelial NO synthase, which controls NO formation from L-ar- ginine, is crucial for the vascular tone maintenance and thrombus development prevention [6, 20, 21, 23].

It is proved that aPL-induced changes in endothelial cells are crucial in cell adhesion to endothelium. In studies on the cultures of human, bull and mouse endothelial cells, it was shown that stimulation of monocyte adhesion by aPL was accompanied by the decrease of NO bioavailability [13].

A dual effect of $\mathrm{NO}$ on myometrium contractile activity during pregnancy was demonstrated in the model of APS induced by lipopolysaccharides. NO was shown to be a uterine relaxant when its concentration was low, but significant decrease in $\mathrm{NO}$ production led to abortion and premature birth. On the other hand, hyperproduction of NO mediated by iNOS increased uterine contractions and the risk of miscarriage [17]. Despite the fact that the pathogenetic aspects of APS are sufficiently studied, there are only a few studies on the involvement of NO in the biochemical mechanisms of vascular complications at APS.

The contradictory of the available information on the role of NO system in the development of pregnancy failure at APS and the data on the effectiveness of NO precursors in reducing of this pathology manifestations necessitates further study of the role of this system in obstetric APS as well as the development of the methods for correction of its complications.

The aim of the research was to estimate the indexes of nitric oxide system in the blood and liver of pregnant animals with an experimental antiphospholipid syndrome before pregnancy and on the $18^{\text {th }}$ day of pregnancy, without treatment and under treatment with nitric oxide synthesis modulators (L-arginine and aminoguanidine).

\section{Materials and Methods}

The studies were conducted using female BALB/c mice, which were kept on a standard vivarium diet. The experiments were performed following the principles of bioethics according to "Ethical Guidelines for the Use of Animals in Research" adopted at the First National Congress on Bioethics (Kyiv, 2001) and consistent with the provisions of the "European convention for the protection of vertebrate animals used for experimental and other scientific purposes" (Strasbourg, 1986) and European Union Directive 2010/63/EU on the protection of animals used for scientific purposes.

APS was simulated by administrating cardiolipin (Sigma, USA) intramuscularly, four injections 
at 14-day intervals (30 $\mu \mathrm{g}$ per 1 injection) [24]. To improve the immune response effectiveness, cardiolipin was emulsified in $75 \mu \mathrm{l}$ of complete Freund's adjuvant for the first injection; the following injections were with the incomplete Freund's adjuvant. APS was developed in 2 weeks after the last cardiolipin injection. Microprecipitation reaction with a cardiolipin antigen, using the test-system "Cardiolipin antigen for microprecipitation reaction” (Biolik, Ukraine), was carried out to confirm APS development [24].

Experimental animals (female BALB/c mice aged 2-3 months, 25-30 g weight, which were kept on a standard vivarium diet, in cages in natural light, temperature $20-22{ }^{\circ} \mathrm{C}$; access to food and water was free) were divided into 10 groups: 1,2 (control) animals without APS; 3, 4- animals with experimental APS; 5, 6 - animals with APS injected with L-arginine hydrochloride (Sigma, USA, $25 \mathrm{mg} / \mathrm{kg}$ ); 7, 8 - animals with APS injected with aminoguanidine (Khimlaboratorreaktyv, Ukraine, 10 mg/kg); 9, 10 - animals with APS injected with L-arginine in combination with aminoguanidine. L-arginine and aminoguanidine were administered intraperitoneally once a day, repeatedly within 27 days after APS development. The identical volumes of the solvent were administered intraperitoneally to the animals of the control group.

The animals of groups 1, 3, 5, 7 and 9 were removed from the experiment using thiopental sodium anaesthesia (intraperitoneal injection of 1\% solution, $50 \mathrm{mg} / \mathrm{kg}$ of animal weight) on the $10^{\text {th }}$ day after APS confirmation. Female mice of the groups $2,4,6,8,10$ were mating with male mice (in the ratio of 1 male to 3 females) in 10 days after the beginning of the therapy and were removed from the experiment on the $18^{\text {th }}$ day of pregnancy using thiopental sodium anaesthesia. The vaginal smears were studied to confirm pregnancy [24].

Liver homogenates and blood serum were used for the study. The liver tissue was cooled in isolation medium containing $0.25 \mathrm{M}$ of sucrose, $1 \mu \mathrm{M}$ edetic acid and $10 \mu \mathrm{M}$ of Tris-HCl buffer ( $\mathrm{pH}$ 7.4). The content of NO in the blood serum and liver homogenates was estimated according to the amount of nitrite $\left(\mathrm{NO}_{2}^{-}\right)$and nitrate anions $\left(\mathrm{NO}_{3}^{-}\right)$as its stable metabolites. $\mathrm{NO}_{2}^{-}$content was determined in the reaction with Gris reagent by spectrophotometric method according to Green L.C. et al [25]. The nitrate reduction to nitrite was performed using zinc metal in the acetic acid solution, the content of $\mathrm{NO}_{2}{ }^{-}$ions was determined by colorimetric method with the use of Gris reagent [26]. The inverse relationship between the level of $\mathrm{NO}$ stable metabolites $\left(\mathrm{NO}_{2}^{-}, \mathrm{NO}_{3}{ }^{-}\right)$in blood serum and uterine cervix and myometrium contractive activity is considered to be a diagnostic criterion for threatened premature birth [27].

The content of eNOS and iNOS in blood serum and liver was determined by ELISA using standard assay kit for mice Mouse NOS3/eNOS (Nitric Oxide Synthase 3, Endothelial) ELISA Kit (Express Biotech International, USA) and Mouse NOS2/iNOS (Nitric Oxide Synthase 2, Inducible) ELISA Kit (Express Biotech International, USA).

Statistical data processing was conducted using STATISTICA 10 program. The comparison of the attained indexes was performed using the Mann-Whitney U-test. The changes were statistically significant at $P \leq 0.05$.

\section{Results and Discussion}

By means of immunoenzyme method, it was established that in mice with APS before pregnancy and on the 18th day of pregnancy, the content of eNOS was decreased in liver (by 66 and 81\%) (Fig. 1) and in blood (by 23 and 67\%) (Fig. 2), while the content of inducible NOS was increased in liver (in 2.2 and 3.5 times) (Fig. 3) and in blood (in 4.1 and 4.5 times) (Fig. 4), respectively, compare to the animals of the control groups.

The results obtained comply with the data on eNOS inhibition under aPL effect that was accompanied by decreased NO synthesis, increased adhesion of leukocytes to the blood vessels endothelium and thrombosis [13].

A significant increase in inducible NOS isoforms activity that may be caused by increased production of proinflammatory cytokines IL-1 $\beta$, IL-6 and TNF- $\alpha$ at APS was evidenced [29, 30].

In our research, it was established that in the animals of groups 3 and 4 with APS, the content of $\mathrm{NO}_{2}^{-}$decreased in blood serum (by 26 and 45\%) and liver (by 13 and 68\%), and the level of $\mathrm{NO}_{3}{ }^{-}$increased in blood serum (by 75 and 60\%) and liver (by 20 and 95\%), respectively as compared to the control (Table 1, 2).

The data of our study on the decrease of $\mathrm{NO}_{2}^{-}$ concentration and increase of $\mathrm{NO}_{3}{ }^{-}$concentration at APS comply with the data of other researches $[3,12]$. In addition, it was established that at primary APS, the content of $\mathrm{NO}_{2}{ }^{-}$decreases depending on the aPL titres and the amount of vascular thrombosis [12]. 


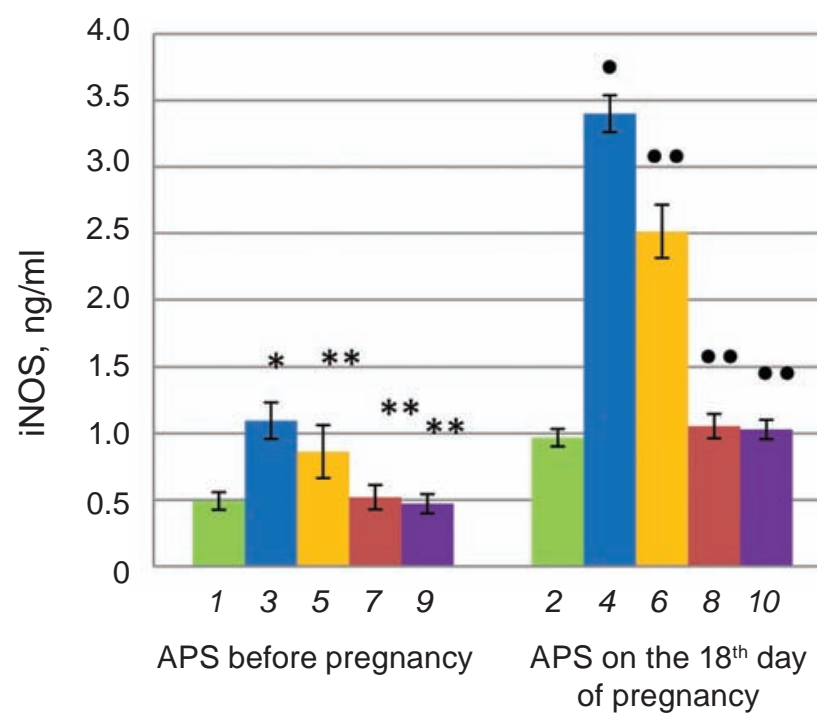

Fig. 1. iNOS content in the liver of mice with APS before pregnancy and on the $18^{\text {th }}$ day of pregnancy in the case of L-arginine and aminoguanidine administration: 1, 2 - control; 3, 4-antiphospholipid syndrome (APS); 5, 6 - APS + L-arginine; 7, 8 APS + aminoguanidine; 9, $10-A P S+L$-arginine + aminoguanidine. $1 \mathrm{ml}$ contains $1 \times 10^{6}$ liver cells. ${ }^{*} \mathrm{P}<0.05$ compare to the control group; ${ }^{* * P}<0.05$ compare to the group of animals with $A P S ; \cdot \bullet P<0.05$ compare to the group of intact animals on the $18^{\text {th }}$ day of pregnancy; $\bullet P P 0.05$ compare to the group of animals with APS on the $18^{\text {th }}$ day of pregnancy

High serum nitrate levels in the patients with APS and in the experimental models are probably caused by an increased content of iNOS-dependent NO. The increase in $\mathrm{NO}_{3}^{-}$level at APS may be a consequence of an increase in the rate of peroxynitrite generation. According to E. Nasonov [3], increased nitrate concentration and recurrent thrombosis in the patients with APS may be evidence of endothelial dysfunction (endothelium-dependent vasodilation) that is typical for this pathology and is apparently associated with oxidative stress development. The fate of NO in biological systems is controlled by three main processes: NO diffusion and intracellular consumption, autooxidation to nitrogen (III) oxide $\left(\mathrm{N}_{2} \mathrm{O}_{3}\right)$, and reaction with superoxide $\left(\mathrm{O}_{2}^{\circ}\right)$, which yields peroxynitrite. Peroxynitrite subsequently may react with carbon dioxide and give rise to various reactive oxygen species and reactive nitrogen species: nitrogen dioxide $\left(\mathrm{NO}_{2}\right)$, carbonate radical $\left(\mathrm{CO}_{3}{ }^{-}\right)$, and hydroxyl radical ('OH) [31].

It was established that endothelial dysfunction under conditions of oxidative stress is associated

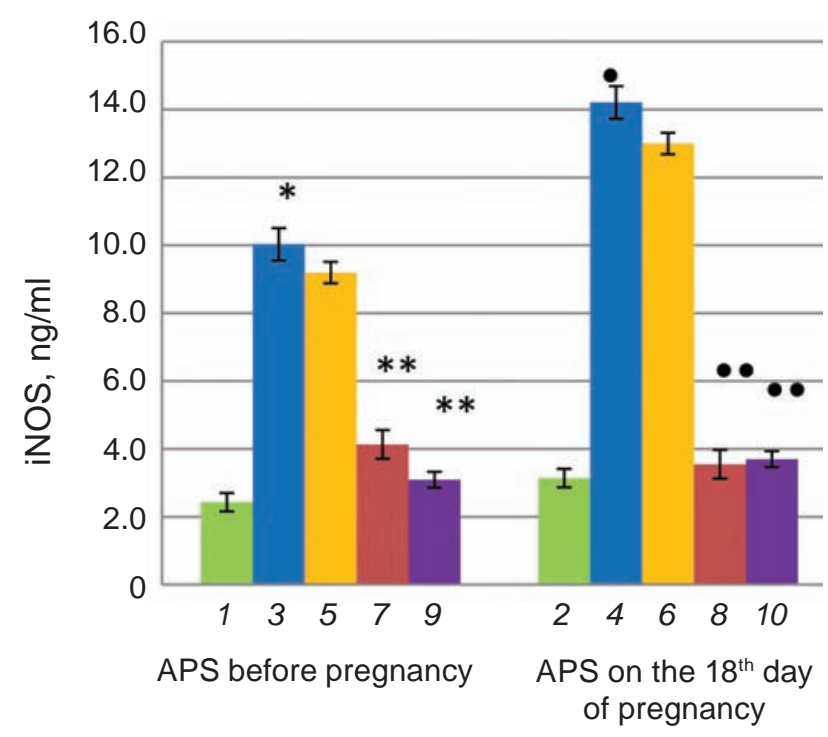

Fig. 2. iNOS content in the blood serum of mice with APS before pregnancy and on the 18th day of pregnancy in case of L-arginine and aminoguanidine administration: 1,2 - control; 3, 4-antiphospholipid syndrome (APS); 5, 6 - APS + L-arginine; 7, 8 APS + aminoguanidine; 9, 10-APS + L-arginine + aminoguanidine. ${ }^{*} P<0.05$ compare to the control group; ${ }^{* * P}<0.05$ compare to the group of animals with APS; $\bullet P<0.05$ compare to the group of intact animals on the $18^{\text {th }}$ day of pregnancy; $\bullet P<0.05$ compare to the group of animals with APS on the $18^{\text {th }}$ day of pregnancy

with the disturbance of NO bioavailability caused by the production of $\mathrm{O}_{2} \div$, which rapidly binds and inactivates NO [3, 23]. On the other hand, a decrease in eNOS activity at APS is also evidenced [32] that was confirmed by the results of our research. As a result, a paradoxical situation could take place in the intrahepatic microcirculation: the flowing blood contains NO; at the same time, a rapidly increased portal flow creates additional pressure on the sinusoidal walls that requires further activation of eNOS and nitric oxide production in the sinusoidal endothelial. However, this does not happen. Apparently, the increased NO concentration in the blood, flowing by the feedback mechanism, rapidly inhibits eNOS expression in the liver. At these conditions, vasodilation deficiency, induced by eNOS, is followed by reducing of sinusoids diameter and increasing of the overall portal vascular resistance. Thus, despite NO hyperproduction, its content at the level of intrahepatic microcirculation could be insufficient [33] that was confirmed by the decrease in the $\mathrm{NO}_{2}{ }^{-}$content in the liver detected in our research. 


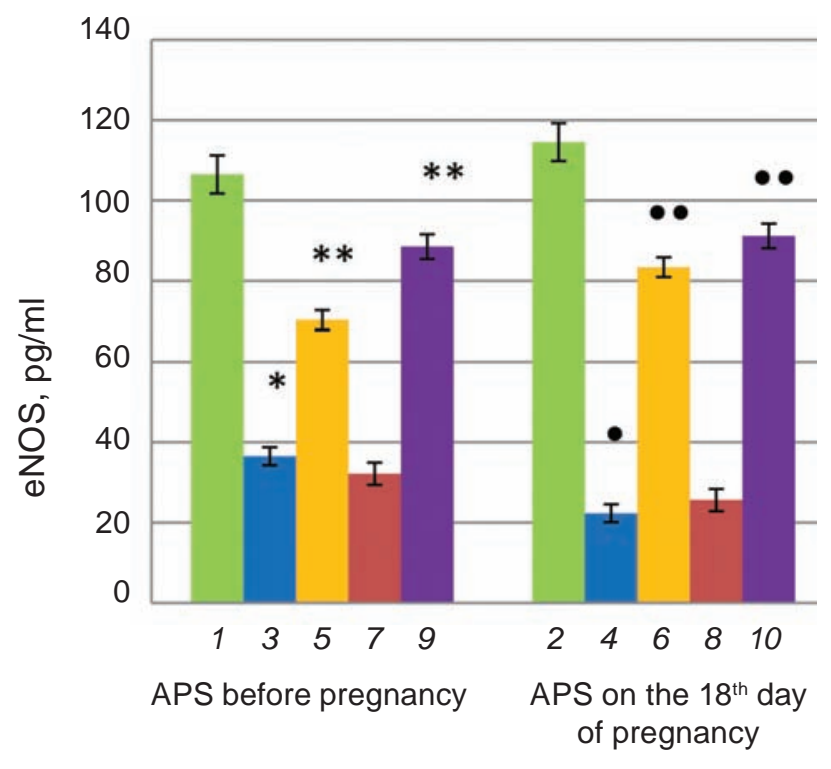

Fig. 3. eNOS content in the liver of mice with APS before pregnancy and on the $18^{\text {th }}$ day of pregnancy in case of L-arginine and aminoguanidine administration: 1, 2 - control; 3, 4 - antiphospholipid syndrome (APS); 5, 6-APS + L-arginine; 7, 8 -APS + aminoguanidine; 9, 10-APS + L-arginine + aminoguanidine. $1 \mathrm{ml}$ contains $1 \times 10^{6}$ liver cells. ${ }^{*} P<0.05$ compare to the control group; ${ }^{* * P}<0.05$ compare to the group of animals with APS; $\bullet P<0.05 \mathrm{com}$ pare to the group of intact animals on the $18^{\text {th }}$ day of pregnancy; $\bullet P<0.05$ compare to the group of animals with APS on the $18^{\text {th }}$ day of pregnancy

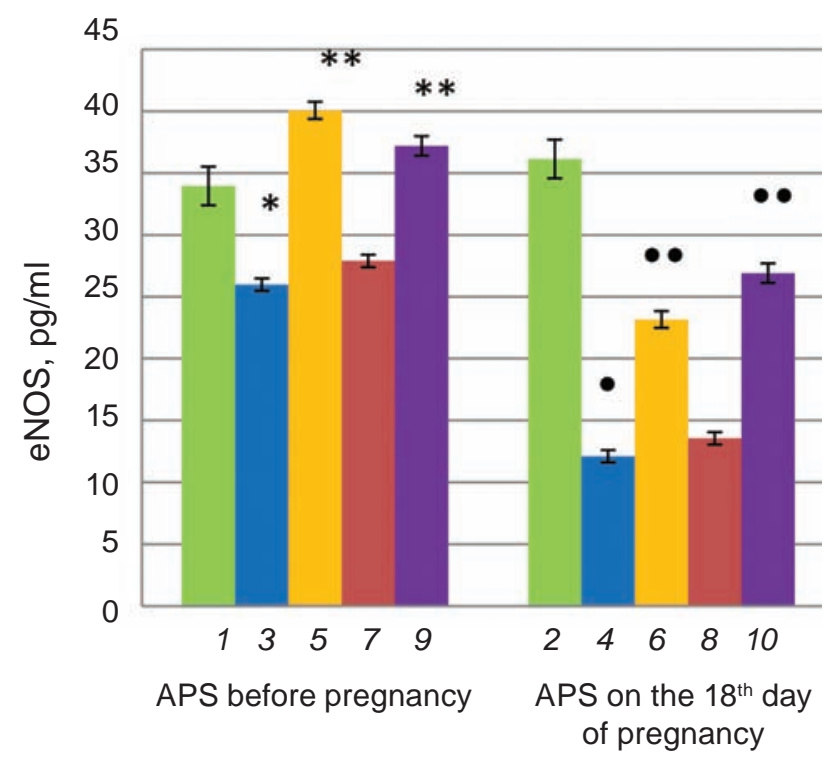

Fig. 4. eNOS content in the blood serum of mice with APS before pregnancy and on the $18^{\text {th }}$ day of pregnancy in case of $L$-arginine and aminoguanidine administration: 1, 2 - control; 3, 4-antiphospholipid syndrome (APS); 5, 6 - APS + L-arginine; 7, 8 APS + aminoguanidine; 9, $10-A P S+L$-arginine + aminoguanidine. $* P<0.05$ compare to the control group; $* * P<0.05$ compare to the group of animals with APS; $\bullet P<0.05$ compare to the group of intact animals on the $18^{\text {th }}$ day of pregnancy; $\bullet P<0.05$ compare to the group of animals with APS on the $18^{\text {th }}$ day of pregnancy

Ta ble 1. $\mathrm{NO}_{2}^{-}$and $\mathrm{NO}_{3}^{-}$content in the blood serum and liver of mice with APS in case of L-arginine and aminoguanidine administration $(M \pm m, n=10)$

\begin{tabular}{l|ccccc}
\hline \multirow{2}{*}{$\begin{array}{c}\text { Group of animals } \\
\text { (experiment series) }\end{array}$} & \multicolumn{3}{c}{ Index } \\
\cline { 2 - 5 } & \multicolumn{2}{|c}{ Blood serum } & \multicolumn{2}{c}{ Liver } \\
\cline { 2 - 5 } & $\mathrm{NO}_{2}^{-}, \mu \mathrm{mol} / 1$ & $\mathrm{NO}_{3}^{-}, \mu \mathrm{mol} / 1$ & $\mathrm{NO}_{2}^{-}, \mu \mathrm{mol} / \mathrm{kg}^{-}$ & $\mathrm{NO}_{3}^{-}, \mu \mathrm{mol} / \mathrm{kg}$ \\
\hline Control & $2.23 \pm 0.10$ & $11.22 \pm 0.48$ & $1.55 \pm 0.05$ & $9.17 \pm 0.35$ \\
APS & $1.65 \pm 0.15$ & $19.65 \pm 0.97$ & $1.35 \pm 0.05$ & $11.01 \pm 0.51$ \\
& $P<0.05$ & $P<0.001$ & $P<0.05$ & $P<0.05$ \\
APS + L-arginine & $2.35 \pm 0.09$ & $30.50 \pm 2.12$ & $1.88 \pm 0.05$ & $15.96 \pm 0.83$ \\
& $P_{1}<0.01$ & $P_{1}<0.005$ & $P_{1}<0.001$ & $P_{1}<0.005$ \\
APS + aminoguanidine & $1.84 \pm 0.10$ & $8.63 \pm 0.30$ & $1.42 \pm 0.03$ & $9.46 \pm 0.28$ \\
& $P_{1}>0.05$ & $P_{1}<0.001$ & $P_{1}>0.05$ & $P_{1}<0.05$ \\
APS + L-arginine + aminoguanidine & $2.06 \pm 0.05$ & $12.82 \pm 1.04$ & $1.69 \pm 0.02$ & $10.20 \pm 0.36$ \\
& $P_{1}<0.05$ & $P_{1}<0.005$ & $P_{1}<0.005$ & $P_{1}>0.05$ \\
\hline
\end{tabular}

Notes: $P$ - statistically significant differences compare to the control group; $P_{1}-$ statistically significant differences compare to the group of animals with APS. 
Ta ble 2. $\mathrm{NO}_{2}^{-}$and $\mathrm{NO}_{3}^{-}$content in the serum and liver of mice with APS on the $18^{\text {th }}$ day of pregnancy in case of L-arginine and aminoguanidine administration $(M \pm m, n=10)$

\begin{tabular}{l|ccccc}
\hline \multirow{2}{*}{\multicolumn{1}{c}{ Group of animals }} & \multicolumn{3}{|c}{ Index } \\
\cline { 2 - 5 } & \multicolumn{2}{|c}{ Blood serum } & \multicolumn{2}{c}{ Liver } \\
\cline { 2 - 5 } & $\mathrm{NO}_{2}^{-}, \mu \mathrm{mol} / 1$ & $\mathrm{NO}_{3}^{-}, \mu \mathrm{mol} / 1$ & $\mathrm{NO}_{2}^{-}, \mu \mathrm{mol} / \mathrm{kg}^{-}$ & $\mathrm{NO}_{3}^{-}, \mu \mathrm{mol} / \mathrm{kg}$ \\
\hline Control & $1.99 \pm 0.08$ & $9.57 \pm 0.58$ & $2.11 \pm 0.08$ & $9.72 \pm 0.31$ \\
APS & $1.10 \pm 0.07$ & $15.29 \pm 0.66$ & $0.68 \pm 0.04$ & $18.94 \pm 0.78$ \\
& $P<0.001$ & $P<0.005$ & $P<0.001$ & $P<0.001$ \\
APS + L-arginine & $1.43 \pm 0.10$ & $24.44 \pm 1.51$ & $1.30 \pm 0.09$ & $22.44 \pm 0.97$ \\
& $P_{1}<0.05$ & $P_{1}<0.005$ & $P_{1}<0.005$ & $P_{1}<0.05$ \\
APS + aminoguanidine & $1.04 \pm 0.04$ & $7.65 \pm 0.37$ & $0.82 \pm 0.03$ & $10.55 \pm 0.22$ \\
& $P_{1}>0.05$ & $P_{1}<0.001$ & $P_{1}<0.05$ & $P_{1}<0.001$ \\
APS + L-arginine + aminoguanidine & $1.51 \pm 0.11$ & $10.82 \pm 0.53$ & $1.94 \pm 0.11$ & $11.41 \pm 0.54$ \\
& $P_{1}<0.05$ & $P_{1}<0.005$ & $P_{1}<0.001$ & $P_{1}<0.001$ \\
\hline
\end{tabular}

Notes: $P$ - statistically significant differences compare to the control group; $P_{1}-$ statistically significant differences compare to the group of animals with APS.

In our opinion, the increase in $\mathrm{NO}_{3}^{-}$level in the blood serum, proved in our studies, is caused by increased iNOS expression in the liver. In the case of reduced substrate content, iNOS can also produce reactive oxygen intermediates and intensify destructive processes in the liver [34].

The involvement of the NO system into the pathogenesis of liver damage at APS allows suggesting the effectiveness of NO-synthases activity modulation to prevent and remove the manifestations of this pathology.

L-arginine, as the precursor in NO synthesis, is known to form H-bond networks with the heme group and amino acid residues inside NOS catalytic site, this ligand-receptor interaction profile is similar in all enzyme isoforms [18, 35].

We proved that L-arginine introduction into the animals with APS before pregnancy and on the $18^{\text {th }}$ day of pregnancy was followed by the increase in the eNOS content in the blood (by 54\% and 92\%) (Fig. 2) and in the liver (in 1.9 and 3.7 times) (Fig. 1); iNOS content in the blood did not changed significantly $(P>0.05)$, while in the liver it was decreased (by 21 and 26\%, respectively) (Fig. 3). In animals with APS injected with L-arginine (groups 5 and 6), the increase in $\mathrm{NO}_{2}^{-}$level in the blood serum (by 42 and 30\%) and in liver (by 39 and 92\%), as well as the increase in $\mathrm{NO}_{3}^{-}$level in blood serum (by 55 and 60\%) and in liver (by 45 and 19\%), was detected respectively, compared to the mice with APS of groups 3 and 4 (Table 1, 2).
Aminoguanidine is structurally similar to L-arginine, it inhibits iNOS selectively and thus reduces NO formation. Aminoguanidine is shown to have antioxidant activity as a scavenger of hydrogen peroxide, hydroxyl radical and superoxide [36].

No significant changes in eNOS content in the blood and liver of mice with APS injected with aminoguanidine before pregnancy and on the $18^{\text {th }}$ day of the pregnancy were observed as compared to the indexes in animals of groups 3 and 4, respectively (Fig. 1, 2).

In the case of aminoguanidine administration, the content of iNOS decreased in the blood (in 2.4 and 4.0 times) (Fig. 4) as well as in the liver (in 2.1 and 3.2 times) (Fig. 3) of animals with APS before pregnancy and on the $18^{\text {th }}$ day of pregnancy, respectively. The level of $\mathrm{NO}_{2}^{-}$did not change significantly both in blood serum $(P>0.05)$ and in the liver of animals with APS before pregnancy, but on the $18^{\text {th }}$ day of pregnancy, it decreased by $21 \%$ (Table 1,2 ). The level of $\mathrm{NO}_{3}^{-}$was also decreased both in blood serum (by 56\% and 50\%) and in the liver (by 14 and 44\%), respectively (Table 1, 2).

Combined administration of L-arginine with aminoguanidine into the animals with APS at the follow-up periods caused a significant increase in eNOS content in blood serum (in 1.4 and 2.2 times) (Fig. 2) and in the liver (in 2.4 and 4.1 times) (Fig. 1) and a significant decrease in iNOS content in blood serum (in 3.2 and 3.8 times) (Fig. 4) and in the liver (in 2.3 and 3.3 times) (Fig. 3). These changes were 
followed by normalization of $\mathrm{NO}_{2}{ }^{-}$and $\mathrm{NO}_{3}{ }^{-}$content both in the blood and in the liver in animals with APS before pregnancy and on the $18^{\text {th }}$ day of pregnancy as compared to the mice with APS in groups 3 and 4 (Table 1, 2).

As it was shown in [37], L-arginine as the precursor of NO synthesis led to positive changes in foetoplacental perfusion in the patients with threatened premature birth that is beneficial for preserving foetal viability. The preterm birth initiation was also observed at NO synthesis inhibition by non-selective NO-synthase suppressor L-NAME. This effect was reduced by using the drugs of the progestin group, which activate inducible NO synthase and thereby increase NO synthesis compensatory [38].

Thus, the results of our research indicate the relative inefficient NO production by eNOS and NO hyperproduction by iNOS in animals with experimental APS. In the case of L-arginine introduction into the animals with APS, the increase in the eNOS, $\mathrm{NO}_{2}^{-}, \mathrm{NO}_{3}^{-}$content in blood serum and liver and the decrease in iNOS content in the liver before pregnancy and on the $18^{\text {th }}$ day of pregnancy were evidenced in comparison with animals with APS only. At aminoguanidine introduction, iNOS content and of $\mathrm{NO}_{3}{ }^{-}$level in blood serum and liver decreased as compared to indexes in animals with APS. Combined administration of L-arginine and aminoguanidine caused the increase in eNOS content and the decrease in iNOS content in blood serum and liver that was followed by normalisation of $\mathrm{NO}_{2}{ }^{-}$and $\mathrm{NO}_{3}{ }^{-}$ content in animals with experimental APS before pregnancy and on the $18^{\text {th }}$ day of pregnancy as compared to untreated mice with APS.

Conflict of interest. Authors have completed the Unified Conflicts of Interest form at http://ukrbiochemjournal.org/wp-content/uploads/2018/12/ coi_disclosure.pdf and declare no conflict of interest.

\section{СТАН СИСТЕМИ ОКСИДУ АЗОТУ \\ ЗА ЕКСПЕРИМЕНТАЛЬНОГО АНТИФОСФОЛІПІДНОГО СИНДРОМУ}

\author{
О. 3. Яремчук , К. А. Посохова, \\ I. П. Кузьмак, М. І. Куліџька, I. М. Кліш, \\ M. М. Корда
}

Тернопільський національний медичний
університет імені I.Я. Горбачевського
®e-mail: yaremchuk@tdmu.edu.ua

Антифосфоліпідний синдром (АФС) є автоімунним захворюванням, що характеризується наявністю антитіл до негативно заряджених мембранних фосфоліпідів (аФЛ). Розвиток ендотеліальної дисфункції за АФС супроводжується тромбозами, плацентарною недостатністю та загибеллю ембріона внаслідок порушення кровообігу в судинах плаценти. Встановлено, що синтез та біодоступність оксиду азоту (NO) в ендотелії за АФС є порушеними, але значення NO системи в підтриманні вагітності за цієї патології залишається нез'ясованим. Метою роботи було оцінити стан системи оксиду азоту за застосування модуляторів синтезу оксиду азоту (L-аргініну та аміногуанідину) у вагітних і невагітних тварин з АФС. У сироватці крові та печінці мишей $\mathrm{BALB} / \mathrm{c} 3$ експериментальним АФС до вагітності та на 18-й день вагітності визначали вміст еNOS та INOS із застосуванням ELISA та вміст стабільних метаболітів оксиду азоту $\mathrm{NO}_{2}^{-}$ та $\mathrm{NO}_{3}{ }^{-}$з використанням реактива Гріса. Одержані дані вказують на недостатню продукцію NO ізоензимом eNOS та гіперпродукцію NO ізоформою iNOS у сироватці крові та печінці мишей в патогенезі АФС. Так, під час АФС вміст eNOS та $\mathrm{NO}_{2}^{-}$знижувався, тоді як iNOS та $\mathrm{NO}_{3}^{-}$ підвищувався порівняно 3 контрольними показниками. Введення мишам 3 AФC L-аргініну призводило до підвищення вмісту еNOS, $\mathrm{NO}_{2}^{-}$, 
$\mathrm{NO}_{3}^{-}$у сироватці крові та печінці в досліджувані терміни відносно показників групи мишей 3 АФС. За комбінованого введення тваринам L-аргініну та селективного інгібітора iNOS аміногуанідину виявлено не лише значне підвищення вмісту eNOS та зниження вмісту iNOS, але й нормалізацію рівня $\mathrm{NO}_{2}{ }^{-}$та $\mathrm{NO}_{3}{ }^{-}$в сироватці крові та печінці мишей з АФС до вагітності та на 18-й день вагітності порівняно з показниками групи мишей з АФС.

К л ю ч о в і с с ова: антифосфоліпідний синдром, оксид азоту, eNOS, iNOS, L-аргінін, аміногуанідин.

\section{References}

1. Collict M, Buhagiar WS, Mercieca C, Thake J. Catastrophic antiphospholipid syndrome in pregnancy: a life-threatening condition. $B M J$ Case Rep. 2019; 12(9): e230863.

2. Fleetwood T, Cantello R, Comi C. Antiphospholipid Syndrome and the Neurologist: From Pathogenesis to Therapy. Front Neurol. 2018; 9: 1001.

3. Nasonov EL. Antiphospholipid syndrome. M.: Litterra, 2004. 440 p. (In Russian).

4. Gornitskaya OV. The antiphospholipid syndrome. Exp Clin Physiol Biochem. 2008; 41(1): 61-70. (In Russian).

5. Arachchillage DRJ, Laffan M. Pathogenesis and management of antiphospholipid syndrome. $\mathrm{Br} \mathrm{J}$ Haematol. 2017; 17(2): 181-195.

6. Posokhova KA, Sak IYu, Sampara SR. Obstetric antiphospholipid syndrome and nitric oxide system (Review of the literature and the results of the research). Med Chem. 2014; 16(1): 73-80. (In Ukrainian).

7. Favaloro EJ. Variability and diagnostic utility of antiphospholipid antibodies including lupus anticoagulants. Int J Lab Hematol. 2013; 35(3): 269-274.

8. Gris JC, Bouvier S. Antiphospholipid syndrome: looking for a refocusing. Thromb Res. 2013; 131(Suppl 1): S28-S31.

9. Ahmadzada VA. Pregnancy and childbirth in antiphospholipid syndrome: clinical course and perinatal mortality. Med Novosti. 2011; (5): 8185. (In Russian).

10. Kharkevich ON, Latnikova EA. Management of pregnancy and childbirth in patients with antiphospholipid syndrome. Med Novosti. 2011; (2): 51-59. (In Russian).
11. Shlyakhtenko TN, Alyab'yeva EA, Arzhanova ON, Selkov SA, Pluzhnikova TA, Chepanov SV. Antiphospholipid syndrome in miscarriage. J Obstet Womens Dis. 2015; 64(5): 69-76. (In Russian).

12. Ames PRJ, Batuca JR, Ciampa A, Iannaccone L, Alves JD. Clinical relevance of nitric oxide metabolites and nitrative stress in thrombotic primary antiphospholipid syndrome. $J$ Rheumatol. 2010; 37(12): 2523-2530.

13. Ramesh S, Morrell CN, Tarango C, Thomas GD, Yuhanna IS, Girardi G, Herz J, Urbanus RT, de Groot PG, Thorpe PE, Salmon JE, Shaul PW, Mineo C. Antiphospholipid antibodies promote leukocyte-endothelial cell adhesion and thrombosis in mice by antagonizing eNOS via beta2GPI and apoER2. J Clin Invest. 2011; 121(1): 120-131.

14. Staub HL, Bertolaccini ML, Khamashta MA. Anti-phosphatidylethanolamine antibody, thromboembolic events and the antiphospholipid syndrome. Autoimmun Rev. 2012; 12(2): 230234.

15. Velásquez M, Rojas M, Abrahams VM, Escudero C, Cadavid AP. Mechanisms of endothelial dysfunction in antiphospholipid syndrome: association with clinical manifestations. Front Physiol. 2018; 9: 1840.

16. Wijetilleka S, Scoble T, Khamashta M. Novel insights into pathogenesis, diagnosis and treatment of antiphospholipid syndrome. Curr Opin Rheumatol. 2012; 24(5): 473-481.

17. Cella M, Farina MG, Dominguez Rubio AP, Di Girolamo G, Ribeiro ML, Franchi AM. Dual effect of nitric oxide on uterine prostaglandin synthesis in a murine model of preterm labour. Br J Pharmacol. 2010; 161(4): 844-855.

18. Ferreira EI, Serafim RAM. Nitric Oxide Synthase Inhibitors. Nitric Oxide Synthase Simple Enzyme-Complex Roles. (May 17th 2017). Available at https://www.intechopen.com/ books/nitric-oxide-synthase-simple-enzymecomplex-roles/nitric-oxide-synthase-inhibitor.

19. Everett TR, Wilkinson IB, Lees CC. Drug development in preeclampsia: a 'no go' area? $J$ Matern Fetal Neonatal Med. 2012; 25(1): 50-52.

20. Moore C, Tymvios C, Emerson M. Functional regulation of vascular and platelet activity during thrombosis by nitric oxide and endothelial nitric oxide synthase. Thromb Haemost. 2010; 104(2): 342-349. 
21. Napoli C, Ignarro LJ. Nitric oxide and pathogenic mechanisms involved in the development of vascular diseases. Arch Pharm Res. 2009; 32(8): 1103-1108.

22. Danylovych HV., Danylovych YuV, Bohach TV, Hurska VT, Kosterin SO. Sources and regulation of nitric oxide synthesis in uterus smooth muscle cells. Ukr Biochem J. 2019; 91(4): 33-40.

23. Lopez-Pedrera Ch, Barbarroja N, JimenezGomez Y, Eduardo Collantes-Estevez E, Aguirre MA, Cuadrado MJ. Oxidative stress in the pathogenesis of atherothrombosis associated with antiphospholipid syndrome and systemic lupus erythematosus: new therapeutic approaches. Rheumatology (Oxford). 2016; 55(12): 2096-2108.

24. Zaichenko HV, Lar'ianovska YuB, Deieva TV. Morphological status of uterus and placenta in experimental model of antiphospholipid syndrome in mice. Ukr Med Almanac. 2011; 14(4): 136-141. (In Ukrainian).

25. Green LC, Wagner DA, Glogowski J, Skipper PL, Wishnok JS, Tannenbaum SR. Analisis of nitrate, nitrite, and [15N]nitrate in biological fluids. Anal Biochem. 1982; 126(1): 131-138.

26. Kiselyk IO, Lutsyk MD, Shevchenko LYu. Features of determination of nitrates and nitrites in blood of patients with viral hepatitis and jaundice of other etiology. Lab Diagnost. 2001; (3): 43-45. (In Ukrainian).

27. Giannella L, Beraldi R, Giulini S, Cerami LB, Mfuta K, Facchinetti F. Nitric oxide metabolite levels and assessment of cervical length in the prediction of preterm delivery among women undergoing symptomatic preterm labor. Int $J$ Gynaecol Obstet. 2012; 116(3): 223-227.

28. Chighizola CB, Ubiali T, Meroni PL. Treatment of Thrombotic Antiphospholipid Syndrome: The Rationale of Current Management - An Insight into Future Approaches. J Immunol Res. 2015; 2015: 951424.

29. Krynytska IYa, Marushchak MI. The indices of nitrogen (II) oxide system in experimental hepatopulmonary syndrome. Ukr Biochem $J$. 2018; 90(5): 91-97.

30. Salim T, Sershen CL, May EE. Investigating the Role of TNF- $\alpha$ and IFN- $\gamma$ Activation on the
Dynamics of iNOS Gene Expression in LPS Stimulated Macrophages. PLoS ONE. 2016; 11(6): e0153289.

31. Manda-Handzlik A, Bystrzycka W, Cieloch A, Glodkowska-Mrowka E, Jankowska-Steifer E, Heropolitanska-Pliszka E, Skrobot A, Muchowicz A, Ciepiela O, Wachowska M, Demkow U. Nitric oxide and peroxynitrite trigger and enhance release of neutrophil extracellular traps. Cell Mol Life Sci. 2019: 1-17.

32. Mineo C. Inhibition of nitric oxide and antiphospholipid antibody-mediated thrombosis. Curr Rheumatol Rep. 2013; 15(5): 324.

33. Wiest R, Groszmann RJ. The paradox of nitric oxide in cirrhosis and portal hypertension: too much, not enough. Hepatology. 2002; 35(2): 478-491.

34. Heusch P, Aker S, Boengler K, Deindl E, van de Sand A, Klein K, Rassaf T, Konietzka I, Sewell A, Menazza S, Canton M, Heusch G, Di Lisa $F$, Schulz R. Increased inducible nitric oxide synthase and arginase II expression in heart failure: no net nitrite/nitrate production and protein S-nitrosylation. Am J Physiol Heart Circ Physiol. 2010; 299(2): H446-H453.

35. Mukherjee P, Cinelli MA, Kang S, Silverman RB. Development of nitric oxide synthase inhibitors for neurodegeneration and neuropathic pain. Chem Soc Rev. 2014; 43(19): 6814-6838.

36. Genç H, Baysal B, Eren B, Yılmaz BD. The Protective Effect of Amino-guanidine, an Inducible Nitric Oxide Synthase Inhibitor, on Aluminium Sulphate Neuro-toxicity in the Rat (Wistar albino) Cerebellar Purkinje Cells: Stereological Study. Middle Black Sea J Health Sci. 2017; 3(3): 7-14.

37. Rytlewski K, Olszanecki R, Lauterbach R, Grzyb A, Kiec-Wilk B, Dembinska-Kiec A, Basta A. Effects of oral L-arginine on the pulsatility indices of umbilical artery and middle cerebral artery in preterm labor. Eur J Obstet Gynecol Reprod Biol. 2008; 138(1): 23-28.

38. Tiboni GM, Del Corso A, Marotta F. Progestational agents prevent preterm birth induced by a nitric oxide synthesis inhibitor in the mouse. In vivo. 2008; 22(4): 447-450. 